\title{
Syndrom DICER1
}

\section{DICER1 Syndrome}

\author{
Hořínová V. ${ }^{1,2}$, Drábová K. ${ }^{3,4}$, Nosková H. ${ }^{5}$, Bajčiová V. ${ }^{4}$, Šoukalová J. ${ }^{3}$, Černá L. ${ }^{6}$, Hůrková V. ${ }^{7}$, Slabý O. ${ }^{8}$, \\ Štěrba J. ${ }^{4}$ \\ 'Ambulance lékařské genetiky, Nemocnice Jihlava \\ ${ }^{2}$ Reprofit, Brno \\ ${ }^{3}$ Oddělení lékařské genetiky, FN Brno \\ ${ }^{4}$ Klinika dětské onkologie, FN Brno \\ ${ }^{5}$ CEITEC - Středoevropský technologický institut, Masarykova univerzita a FN Brno \\ ${ }^{6}$ Gennet, Praha \\ 7 PREDIKO, Zlín \\ ${ }^{8}$ Klinika komplexní onkologické péče, Masarykův onkologický ústav, Brno
}

\section{Souhrn}

Syndrom DICER1 je familiární nádorový a dysplastický syndrom způsobený mutacemi v genu DICER1, který se nachází na 14. chromozomu v oblasti q32.13. Součástí syndromu je nejčastěji pleuropulmonální blastom (PPB), multinodulární struma, nádory ze Sertoliho buněk a další nádory. PPB je vzácný nádor, jehož základy většinou začínají ve fetálním období při vývoji plic. Příznaky se objevují v prvních 5 letech života, nejčastěji do 2 let. Diagnóza PPB by vždy měla vést $k$ vyloučení syndromu DICER1. Asi u $35 \%$ rodin, v nichž má dítě projevy PPB, se vyskytují další malignity, které se jinak objevují vzácně. Jedná se o cystický nefrom, nádory ze Sertoliho buněk, nodulární dysplazie štítné žlázy, meduloepitheliom duhovky, embryonální rabdomyosarkom botryoidního typu, chondromezenchymální hamartom nosní sliznice, pituitární blastom a pineoblastom. Rozsáhlé studie ukázaly velkou variabilitu nádorů. Syndrom DICER1 je razen $\mathrm{k}$ nádorovým predispozičním syndromům. Dědí se autozomálně dominantně, časté jsou nové mutace, tzv. mutace de novo. Příznaky u postižených jsou různé i v rámci rodiny. Preventivní sledování nositelů mutace v genu DICER1 je obtižné. Doporučení ke sledování jsou podle Mezinárodního registru PPB z roku 2016.

\section{Klíčová slova}

genetické testování - dědičné nádorové syndromy - DICER1 - pleuropulmonální blastom cystický nefrom

\section{Summary}

DICER1 syndrome is an inherited disorder that increases the risk of different types of malignant and benign tumors. The syndrome is caused by mutations in the DICER1 gene, which is located on the long arm of chromosome 14, region q32.13. Patients with DICER1 syndrome commonly develop pleuropulmonary blastoma (PPB), multinodular goiter, ovarian Sertoli-Leydig cell tumors, and/or other types of tumors. In approximately $35 \%$ of families with children manifesting PPB, further (and rather rare) malignancies may be observed, including cystic nephroma, nodular dysplasia of the thyroid gland, medulloepithelioma of the iris, embryonal rhabdomyosarcoma botryoid type, nasal epithelial hamartoma, pituitary blastoma, and/or pineoblastoma. Large studies report a high variability of tumors associated with DICER1. DICER1 syndrome, which is associated with an inherited predisposition to tumors, is inherited in an autosomal dominant pattern. Symptoms of DICER1 syndrome may vary, even within families. Preventive screening of carriers with causative mutations is complicated. Follow-up is undertaken as recommended by the 2016 International PPB Register.

\section{Key words}

genetic testing - hereditary cancer syndromes - DICER1 - pleuropulmonary blastoma - cystic nephroma
Práce byla podpořena grantovým projektem Ministerstva zdravotnictví ČR AZV 16-3329A.

This work was supported by grant of Ministry of Health of the Czech Republic AZV 16-3329A.

Autoři deklarují, že v souvislosti s předmětem studie nemají žádné komerční zájmy.

The authors declare they have no potential conflicts of interest concerning drugs, products, or services used in the study.

Redakční rada potvrzuje, že rukopis práce splnil ICMJE kritéria pro publikace zasílané do biomedicínských časopisů.

The Editorial Board declares that the manuscript met the ICMJE recommendation for biomedical papers.

MUDr. Věra Hořínová

Ambulance lékařské genetiky

Nemocnice Jihlava

Vrchlického 4630/59

58601 Jihlava

e-mail: horinovav@seznam.cz

MUDr. Klára Drábová, Ph.D.

Oddělení lékařské genetiky

FN Brno

Jihlavská 20

62500 Brno

e-mail: drabova.klara@fnbrno.cz

Obdrženo/Submitted: 4. 6. 2019

Príijato/Accepted: 6. 6. 2019

doi: 10.14735/amko2019S123 


\section{Charakteristika syndromu}

Syndrom DICER1 je dědičné onemocnění, které zvyšuje riziko vzniku řady nádorových onemocnění, a to jak maligních, tak benigních. Lze jej najít také pod názvem pleuropulmonální blastom (PPB). Součástí syndromu DICER1 je nejčastěji maligní $P P B$, benigní cystický nefrom, dále multinodulární struma a také karcinom štítné žlázy či nádory ze Sertoliho buněk a další nádory. Postižení jedinci mohou vyvinout jeden nádor nebo i více typů nádorů, které se jinak objevují vzácně. Kromě výše jmenovaných sem patři např. meduloepitheliom duhovky, embryonální rabdomyosarkom botryoidního typu, chondromezenchymální hamartom nosní sliznice, pituitární blastom a pineoblastom. Častěji se u pacientů s tímto syndromem vyskytují i další nádory hlavy a krku a gastrointestinální polypy. Rozsáhlé studie ukázaly velkou variabilitu nádorů. Členové jedné rodiny mohou mít různé typy nádorů nebo se u nich nádor nemusí projevit vůbec. Jedná se tedy o autozomálně dominantně dědičné onemocnění se sníženou penetrancí. Penetrance benigních útvarů, jako jsou uzly ve štítné žláze, je vysoká a týká se spíše dospělého věku. Syndrom DICER1 je řazen k nádorovým predispozičním syndromům (OMIM *606241, \#601200) [1]. Prevalence dle Exome Aggregation Consortium je přibližně $1: 2529$ - $1: 10600$ [2,3]. Riziko tvorby nádorů u jedinců se syndromem DICER1 je ve srovnání se zdravou populací mírně zvýšeno. Podle Stewarta et al [4] je riziko vzniku PPB do 10 let věku asi 5,3\% (s maximem 9,7 \%), riziko ostatních nádorů (nejvíce karcinomu štítné žlázy a nádorů ze Sertoliho-Leydigových buněk) je až 19,3 \% do 50 let věku (s maximem $29 \%$ ). U žen je riziko s věkem vyšší než u mužů.

PPB je nejčastější primární plicní nádor dětského věku, je to vzácný embryonální nádor, jehož základy většinou začínají ve fetálním období při vývoji plic. Existují tři typy PPB - multicystické léze (typ I, s 5letým celkovým přežitím (overall survival - OS) $91 \%$ ), smíšený cysticko-solidní (typ II, s 5letým OS 74 \%) a solidní (typ III, s 5letým OS 53 \%) [5]. Př́znaky se většinou objeví v prvních 5 letech života, nejčastěji do 2 let. Diagnóza PPB by vždy měla vést $\mathrm{k}$ vyloučení syndromu DICER1. Na rozvoji PPB se podílejí buňky epiteliální i mezenchymální. Na začátku tumorigeneze se objevují cysty $v$ plicních sklípcích. Tyto cysty jsou spojeny $s$ benigní epiteliální změnou. Mezenchymální buňky mají maligní potenciál. Zmnožení mezenchymálních buněk může vést až k rozvoji sarkomu plic se závažnou prognózou [6]. Asi u 35 \% rodin, kde dítě má projevy PPB, bývají další malignity, které se jinak objevuji vzácně (viz výše) (OMIM \#601200) [7].

\section{Diagnóza}

Diagnóza jednotlivých nádorů u syndromu DICER1 závisí na jejich klinické prezentaci, která souvisí s typem nádoru, věkem nemocného a rodinnou anamnézou.

\section{Léčba}

Záleží na typu nádoru a stavu jeho rozvoje. U benigních útvarů se nejčastěji jedná o chirurgickou resekci, u maligních nádorů o biopsii s následnou chemoterapií, někdy také radioterapií. Karcinom štítné žlázy se léčí mimo jiné aplikací radiojodu. $\mathrm{V}$ indikovaných prípadech se používá experimentální či biologická léčba.

\section{Genetická poradna}

Syndrom DICER1 je autozomálně dominantně dědičný s $50 \%$ pravděpodobností přenosu mutace na potomky. V $80 \%$ se jedná o familiární mutace, ve $20 \%$ o mutace de novo [8]. Ani v př́padě kdy se $v$ rodině vyskytuje pouze jeden nemocný, se nemusí jednat o novou mutaci, protože se u některých členů rodiny syndrom neprojeví nebo se projeví pouze s benigní afekcí, např. uzly ve štítné žláze. Navíc také nemusíme mít o rodině úplné informace.

Pokrevním přibuzným v riziku se vždy nabízí molekulárně genetické testování, a to $z$ důvodu možného sledování a včasného zákroku.Pokud je testovánízahájeno v důsledku známé familiární DICER1 patogenní varianty, je doporučeno upřednostnění prediktivního testování př́buzných 1. stupně. U novorozenců se doporučuje testování do 4 měsíců věku, aby mohl být plicní screening zahájen pouze u ohrožených dětí [2].
$V$ případě známé mutace lze $v$ rodině zajistit preimplantační genetické vyšetření embryí. Prenatální diagnostika může narazit na etiku ukončování gravidity $v$ prípadě výskytu mutace $v$ genu DICER1 z důvodu relativně nízké penetrance výskytu maligních nádorů.

\section{Další sledování}

Mezinárodní registr PPB svolal v květnu 2016 inaugurační mezinárodní sympozium DICER1 za účelem vypracování konsenzuálního testování, sledování a doporučení léčby u pacientů s mutací genu DICER1 [2,9]. Účastníci z celého světa se domlouvali na doporučeních pro genetické testování, prenatální léčbu a sledování plicní, renální, gynekologické, štítné žlázy, oftalmologie, otolaryngologie, nádorů centrálního nervového systému a gastrointestinálních polypů. Riziko pro většinu novotvarů spojených s DICER1 syndromem je nejvyšší v raném dětství a snižuje se $v$ dospělosti. Primární doporučené přístupy jsou individuální a založené na zobrazovacích metodách. Tato doporučení pro testování a sledování odrážejí konsenzus odborných posudků a současné literatury. Jak se výzkum syndromu DICER1 rozšiřuje, budou i nadále aktualizovány pokyny pro sledování a léčbu [2].

Doporučení pro screening musí brát v úvahu typický věk nástupu, potenciální prínosy včasné detekce a rizika a dostupnost screeningových modalit (např. radiační expozice, potřeba celkové anestezie u malých dětí a pravděpodobnost falešně pozitivních nálezů). Důrazně se doporučuje individuální př́istup podle rodinné anamnézy. Kromě sledování založeného na zobrazovacích metodách by jednotlivci a rodiny měli být při každé návštěvě poučeni o možných příznacích stavů spojených se syndromem DICER1.

$U$ těhotných žen, jejichž plody jsou ohroženy patogenní zárodečnou DICER 1 variantou $z$ mateřské nebo otcovské strany, se doporučuje ultrazvuk (UZ) ve 3. trimestru, aby byly detekovány velké plicní cysty, které mohou vyžadovat časnou intervenci po porodu. Prenatální UZ má také vyšší citlivost na cystické plicní onemocnění než neonatální rentgenový (RT) snímek. Na základě zkušeností z ji- 
ných stavů charakterizovaných cystickými plicními lézemi [2] vyžadují cysty pozorované na prenatálním UZ sledování počítačovou tomografií (computed tomography - CT) i v prípadě, že je RT hrudníku při narození normální.

Dále je doporučen RT hrudníku při narození pro všechny děti s rizikem patogenní varianty DICER1 v zárodečné linii, aby bylo možné vyšetřit velké plicní cysty. $U$ dětí s potvrzenou mutací DICER1 genu by mělo být první CT hrudníku provedeno ve věku 9 měsíců, nejlépe ve věku 3 až 6 měsíců, protože výskyt PPB typu II a III vzrůstá po jednom roce věku. $V$ prípadě neprítomnosti plicních cyst/PPB většina jedinců s mutacemi v genu DICER1 detekovanými v raném dětství podstoupí pouze dvě hrudní $C T$. Pokud je první CT hrudníku normální, bez známek cyst, doporučuje se následné $C T$ hrudníku přibližně ve věku 2,5-3 let, před dosažením maximálního výskytu PPB. Při absenci radiografických nálezů se doporučuje standardní RT hrudníku každých 6 měsíců od narození do 8 let věku a poté každoročně od 8 do 12 let. Využití rutinního sledování RT nebo CT v dospívání a dospělosti není známo, a proto se nedoporučuje. $V$ současné době $C T$ nabízí vyšší úroveň citlivosti pro detekci cystických plicních lézí, které nelze dosáhnout samotným RT. Při provádění $C T$ by měly být zahrnuty techniky minimalizace ozáření. Vzhledem $\mathrm{k}$ tomu, že jsou vyvinuty nové metody magnetické rezonance, které nakonec umožní detekci malých cystických lézí, měl by být zvážen přechod na ne-radiaci obsahující průřezové zobrazení. Při nálezu plicní cysty na zobrazovacích vyšetřeních se dále postupuje individuálně dle věku postiženého, klinického stavu, možnosti resekce a dalších faktorů $[2,9]$. Vždy se konzultuje onkolog a chirurg.

Dalším častým nádorem spojeným se syndromem DICER1 je cystický nefrom, Wilmsův tumor, anaplastický sarkom ledviny či renální karcinom. Afekce se často vyskytují oboustranně. Je doporučen UZ břicha $v$ dětství $v$ době prvního CT hrudníku a každých 6-12 měsíců do věku nejméně 8 let. Roční UZ po 8 letech věku může být zvažován do 12 let věku na základě rodinné anamnézy. Normální UZ a/nebo resekce cystického

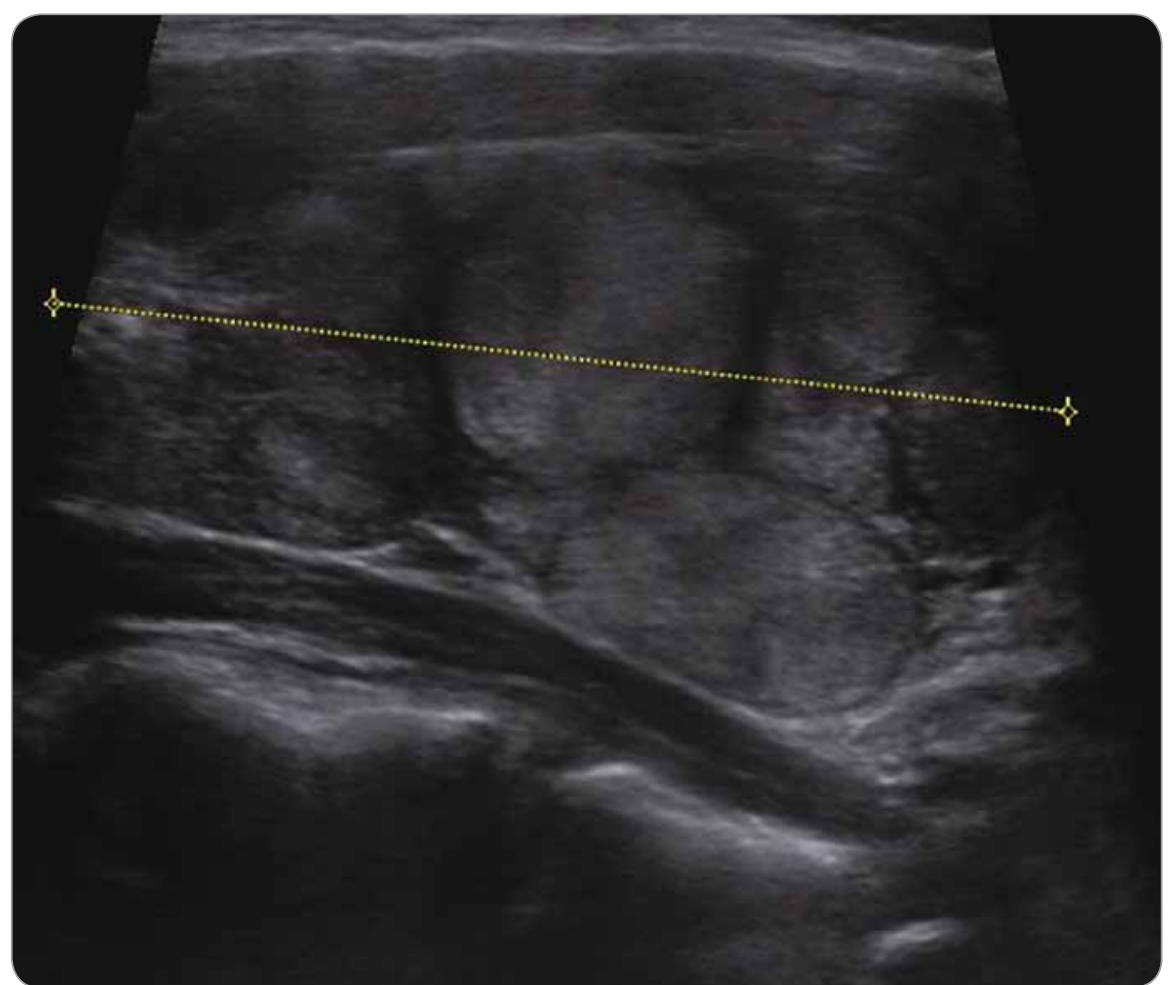

Obr. 1. Ultrazvukové vyšetření pacientky z kazuistiky 1 - folikulární karcinom štítné žlázy, pT1 N0 M0.

nefromu v raném dětství předpovídá nižší pravděpodobnost pozdější renální malignity [9].

Vzhledem ke zvýšenému riziku vzniku uzlů štítné žlázy a karcinomu štítné žlázy se doporučuje první UZ nejpozději ve věku přibližně 8 let a pak každé 2 až 3 roky nebo podle aktuálního klinického stavu (zvětšení štítné žlázy, uzly štítné žlázy nebo perzistentní cervikální lymfadenopatie, potíže s polykáním atd.). U jedinců, u kterých byla diagnostikována jiná afekce spojená s DICER1 syndromem (např. PPB, pineoblastom, cystický nefrom), by měl být $v$ době stanovení diagnózy proveden základní UZ štítné žlázy. Všechny uzly štítné žlázy by měly být vyšetřeny aspirací jemnou jehlou s cytopatologickým vyšetřením [2,9]. Opět se ř́díme rodinnou anamnézou.

Zatím nejsou přesná doporučení pro screeningová vyšetření pro výskyt nádorů ženských pohlavních orgánů (nádory ze Sertoliho-Leydigových buněk, gynandroblastomy, botryoidní rabdomyosarkom čípku, příp. další). Pacientky musí být pečlivě poučeny o příznacích jmenovaných nádorů (břišní či pánevní bolest, hmatná rezistence, virili- zace, předčasná puberta, nepravidelnost menstruačního cyklu, vaginální krvácení u prepubertálních dívek). Standardně se provádí UZ břicha každých 6-12 měsíců $v$ průběhu celého dětství spolu s vyšetřením ledvin (viz výše), dále pak UZ břicha 1 krát ročně a pravidelná gynekologická vyšetření vč. transvaginálního UZ každých 6-12 měsíců v průběhu celého adultního věku [9]. Vzhledem $\mathrm{k}$ tomu, že dobře diferencované formy nádorů ze Sertoliho-Leydigových buněk se vyskytují ve všech věkových kategoriích a jsou velmi vzácné, je doporučováno, aby všichni pacienti s těmito nádory byli odesláni na genetické pracoviště za účelem vyšetření genu DICER1.

Vzhledem k vzácnému výskytu nádorů hypofýzy a pineoblastomu i v podmínkách spojených se syndromem DICER1 zůstává úloha preventivní magnetické rezonance u asymptomatických jedinců kontroverzní. V př́padě výskytu příznaků intrakraniálních nádorů (Cushingův syndrom, diabetes insipidus, príznaky zvýšeného intrakraniálního tlaku, zvracení, letargie, neurologické změny, oftalmoplegie aj.) je doporučeno provést magnetickou rezonanci mozku $[2,9]$. 

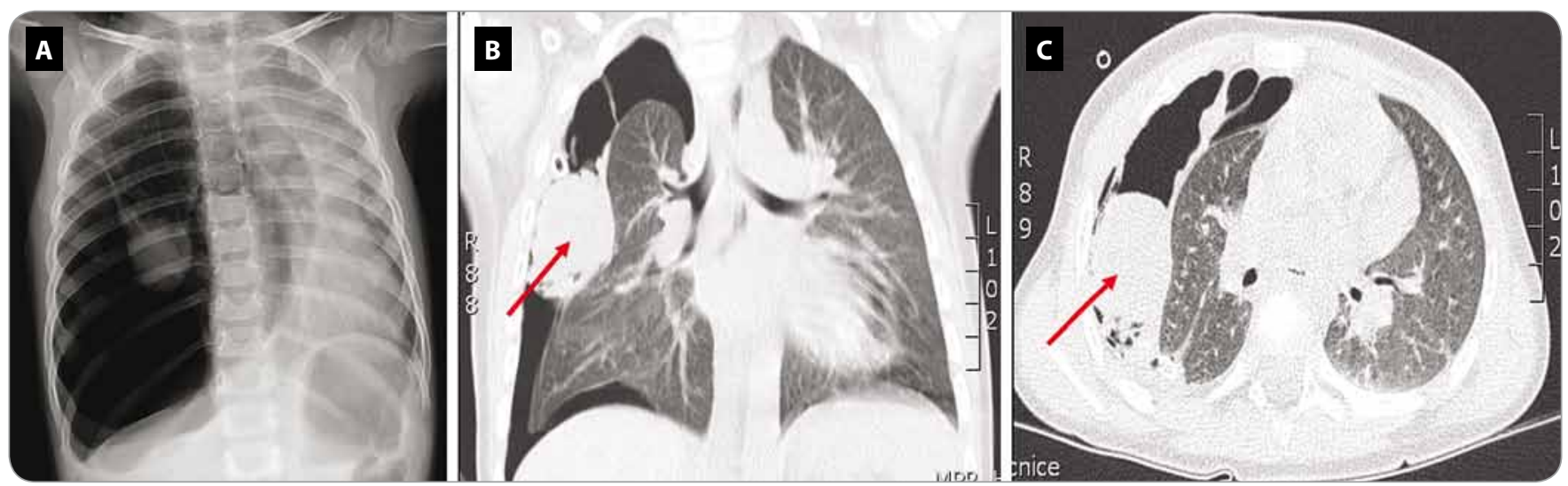

Obr. 2. Vyšetření pacientky z kazuistiky 2. A. Rentgen hrudníku. B, C. Počítačová tomografie plic - pleuropulmonální blastom v době stanovení diagnózy.
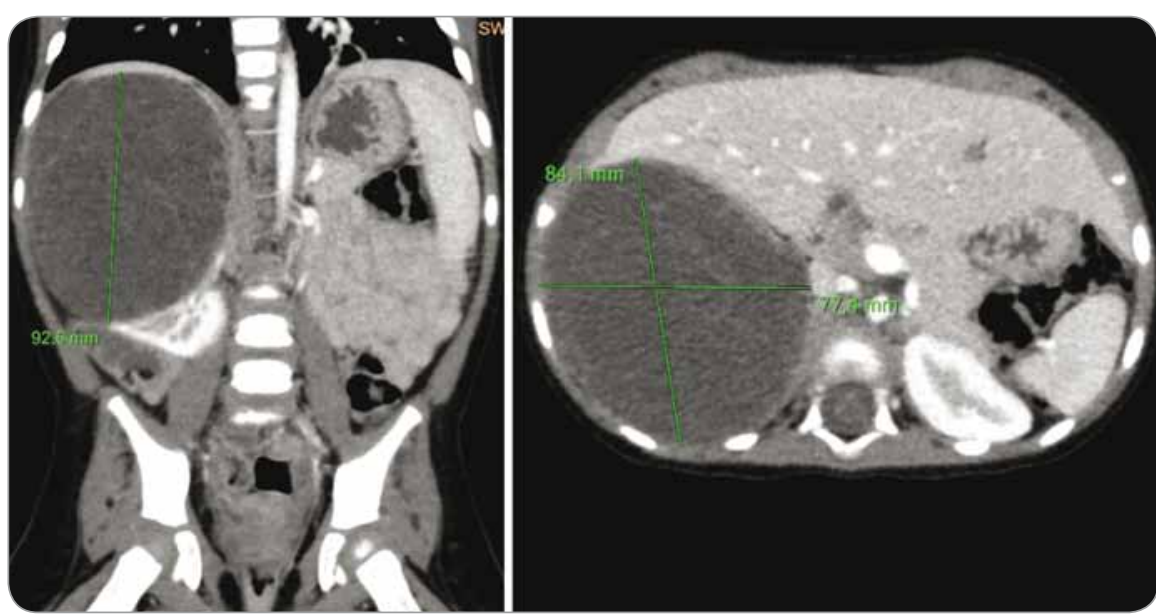

Obr. 3. Počítačová tomografie břicha pacientky z kazuistiky 3 - cystický nefrom pravé ledviny.

V případě nově vzniklého strabizmu, leukokorie či poruchy vizu je také vhodné provést oční vyšetření vč. vyšetření očního pozadí. Pravidelná oční vyšetření se doporučují individuálně. Při gastrointestinálních potížích je také dobré myslet na častější výskyt gastrointestinálních polypů spojených s tímto syndromem, indikace endoskopických vyšetření se rí́dí klinickými příznaky [9].

Podrobnější informace jsou k dispozici na internetových stránkách Mezinárodního registru PPB [10] nebo v pokynech pro Evropskou skupinu velmi vzácných nádorů [11].

\section{Kazuistika 1}

Žena ve věku 22 let byla odeslána do genetické poradny ošetřujícím gynekologem po operaci myomu dělohy v květnu 2016. $Z$ anamnézy při genetickém vyšetření vyplynulo, že byla ve 3 letech operovaná pro cystu ledviny, histologicky se jednalo o cystický nefrom.V roce 2007 (ve 12 letech) byla léčena na Klinice dětské onkologie (KDO) FN Brno pro botryoidní rabdomyosarkom děložního čípku, IRS (Intergroup Rhabdomyosarcoma Studies) skupina II, proběhla operace, reoperace a systémová chemoterapie. V roce 2014 (v 19 letech) jí byl zjištěn invazivní folikulární karcinom štítné žlázy, lokalizovaná nemoc (obr. 1). Absolvovala totální thyreoidektomii a léčbu radiojodem. V současnosti se cítí zdravá, uvádí normální životosprávu, kouří tři cigarety za den. Genealogie zcela bez onkologické zátěže.

Vzhledem k anamnéze a klinice bylo indikováno vyšetření CZECANCA (NimbleGen SeqCap EZ Choise Cancer Panel). Byla nalezena mutace v genu DICER1 - sestřihová varianta c.4051-1G>T (NM_177438.2). Tato varianta nebyla dosud popsána $v$ databázích ClinVar, LOVD ani HGMD, proto byla ověřena a potvrzena analýzou ribonukleové kyseliny. Varianta se nachází ve vysoce konzervovaném místě rozpoznávaném sestřihovým komplexem, je proto pravděpodobné, že může způsobovat nižší afinitu sestřihového komplexu k sestřihovému místu, které následně nemusí být tímto komplexem rozpoznáno. Tři predikční programy (MaxEnt, NNSPLICE a SSF) se shodují, že s nejvyšší pravděpodobností dojde ke ztrátě akceptorového místa v intronu 21 a následně tak dojde k vynechání exonu 22. Vzhledem k prodělaným malignitám jsme vyhodnotili variantu jako IARC (Mezinárodní agentura pro výzkum rakoviny) - class 4, pravděpodobně patogenní.

Pacientka byla o diagnóze informována, bylo jí doporučeno preventivní sledování a dovyšetření pokrevních členů rodiny $v$ riziku, tj. bratrů a rodičů. Vzhledem k negativní genealogii je možno uvažovat o mutaci de novo, segregace nalezené varianty však nebyla provedena pro nespolupráci rodiny.

Dále jí byla vysvětlena možnost preimplantační genetické diagnostiky embryí v př́padě plánování rodiny. Zda bude dodržovat preventivní opatření a doporučení a v případě plánovaní gravidity podstoupí preimplantační genetické vyšetření embryí, není jasné. Zatím si totiž pacientka závažnost diagnózy nepřipouští.

\section{Kazuistika 2}

Další kazuistika popisuje dívku narozenou $v$ roce 2008 . Perinatální anamnéza je negativní. Do 2 let nebyla dívka významně nemocná. Ve 2 letech byla hospitalizována pro dušnost na pediatrické klinice. Základní klinické i biochemické vyšet- 
ření bylo negativní. Bylo provedeno rentgenové vyšetření srdce a plic a zjištěn pneumotorax vpravo, byl zaveden hrudní drén na aktivní sání. Pro přetrvávající dušnost bylo provedeno $C T$ vyšetření - pravá plíce částečně zkolabovaná, na viscerální pleuru nasedal nehomogenně se sytící nádor (obr. 2). Jako vedlejší nález byla ventrálně od hilu levé ledviny detekována kulovitá cystoidní formace. Probandka byla přeložena na KDO. Na základě radiologického nálezu a věku bylo vyjádřeno podezření na PPB. V červnu 2010 proběhla thorakoskopická parciální resekce nádoru. Histologicky byl potvrzen PPB, typ II. Dívka absolvovala systémovou protinádorovou léčbu a dosáhla první kompletní remise. $\checkmark$ roce 2017 bylo cystické ložisko pravé ledviny biopticky verifikováno jako cystický nefrom. Vzhledem k souběhu PPB a cystického nefromu bylo vysloveno podezření na syndrom DICER1. Dívka byla zároveň sledována pro uzly ve štítné žláze - ve FN Motol proběhla v červnu 2017 biopsie a byl potvrzen folikulární karcinom štítné žlázy. Nyní je pacientka po totální thyreoidektomii a léčbě radiojodem. Progrese cystického nefromu v pravé ledvině s destrukcí parenchymu si vynutila pravostrannou nefrektomii. V lednu 2018 byl zjištěn nález vícečetných cystických nefromů v solitární levé ledvině, pro které je v současné době léčena experimentální biologickou léčbou (mTOR inhibitory). Při další progresi je pacientka v riziku levostranné nefrektomie a kandidátkou následné transplantace ledviny.

Sangerovým sekvenováním byla nalezena sestřihová varianta c.2889-2A>G (NM_177438.2) na hraničním místě 16. a 17. exonu genu DICER1 v heterozygotní formě. Tato varianta nebyla v databázích dosud popsána. Nachází se ve vysoce konzervovaném místě rozpoznávaném sestřihovým komplexem. Podle predikčního programu Sroogle varianta pravděpodobně způsobuje nižší afinitu sestřihového komplexu $\mathrm{k}$ akceptorovému místu $v$ intronu 16, a následně tak může dojít k vynechání exonu 17 genu DICER1. Varianta byla klasifikována jako IARC class 4 , pravděpodobně patogenní.

Z genealogie plyne, že sestra matky měla diagnostikován ve 37 letech kožní melanom a otec matky měl tumor ledviny (blíže nespecifikovaný). Jinak je rodina bez onkologické zátěže.

Bylo provedeno vyšetření rodičů. Ani jeden z rodičů uvedenou variantu v genu DICER1 nepřenáší. Jedná se tedy o mutaci de novo.

\section{Kazuistika 3}

Poslední kazuistika popisuje případ 2leté dívky. Perinatální anamnéza nebyla spojená s patologií. Do 2 let pacientka prodělala pouze běžné infekty. Ve 2 letech byla hospitalizována pro respirační febrilní infekt. V komplexním vyšetření byla prokázána hematurie a leukocyturie, klinicky byl stav vyhodnocen jako zánět močových cest, a proto byla nasazena antibiotika, celkový stav pacientky se poté zlepšil. Po propuštění byla dívka odeslána ke sledování do nefrologické ambulance. Zde byl v lednu 2018 proveden UZ břicha a byl zjištěn multicystický útvar ledviny vpravo. Pacientka byla odeslána na KDO. Po vstupním stagingu byla na základě radiologického obrazu a velikosti ložiska indikována primární nefrektomie (obr. 3). Histologicky se jednalo o benigní cystický nefrom. Adjuvantní onkologická léčba nebyla indikována, dívka je dále sledována $v$ ambulanci KDO. Vzhledem k charakteru nádoru bylo vysloveno podezření na syndrom DICER1.

Sangerovým sekvenováním byla nalezena nonsense varianta c.2534T>A/p. L845* (NM_177438.2) v 16. exonu genu DICER 1 v heterozygotním stavu, která má za následek vznik předčasného terminačního kodonu a následně tak vznik proteinu $s$ pozměněnou strukturou a funkcí. Varianta nebyla dríve popsána. Klasifikována byla jako IARC - class 4, pravděpodobně patogenní.

Genealogie je bez významné onkologické zátěže, pouze dědeček ze strany matky měl nádor prostaty a tlustého střeva v pokročilém věku.

Segregace mutace $v$ rodině nebyla pro nespolupráci rodiny provedena.

\section{Závěr}

Syndrom DICER1 je predispoziční nádorový syndrom, pro který jsou charakteristické určité typy maligních nádorů, ale i benigních dysplazií s velmi variabilními příznaky. Většina jedinců s patogenními zárodečnými variantami genu DICER1 je naštěstí zdravá nebo má pouze benigní typ nádoru, presto je vhodné tyto pacienty pravidelně sledovat. V prípadě výskytu uvedených typů nádorů je dobré na tento syndrom myslet.

\section{Literatura}

1. Slade I, Bacchelli CH, Davies H et al. DICER1 syndrome; clarifying the diagnosis, clinical futures and management implications of a pleiotropic tumor predisposition syndrome. J Med Genet 2011; 48(4): 273-278. doi: 10.1136/jmg.2010.083790.

2. Schultz KA, Williams GM, Kamihara J et al. DICER1 and associated conditions: identification of at-risk individuals and recommended surveillance strategies. Clin Cancer Res 2018; 24(10): 2251-2261. doi: 10.1158/1078-0432. CCR-17-3089

3. Kim J, Field A, Schultz KA et al. The prevalence of DICER1 pathogenic variation in population databases. Int J Cancer 2017; 141(10): 2030-2036. doi: 10.1002/ijc.30907. 4. Stewart DR, Best AF, Williams GM et al. Neoplasm risk among individuals with a pathogenic germline variant in DICER1. J Clin Oncol 2019; 37(8): 668-676. doi: 10.1200/JCO.2018.78.4678.

5. Hill DA, Dehner LP. A cautionary note about congenital cystic adenomatoid malformation (CCAM) type 4. Am J Surg Pathol 2004; 28(4): 554-555.

6. Hill DA, Ivanovich J, Priest JR et al. Germline DICER1 mutations in familial pleuropulmonary blastoma. Science 2009; 325(5943): 965. doi: 10.1126/science.1174334.

7. Priest JR, Watterson J, Strong L. Pleuropulmonary blastoma: a marker for familial disease. J Pediatr 1996; 128(2): 220-224.

8. Doros L, Schultz KA, Stewart DR et al. DICER1-related disorders: genereviews. [online]. Available from: http://www.ncbi.nlm.nih.gov/books/NBK196157/.

9. Schultz KA, Rednam SP, Kamihara J et al. PTEN, DICER1, $\mathrm{FH}$, and their associated tumor susceptibility syndromes: clinical features, genetics, and surveillance recommendations in childhood. Clin Cancer Res 2017; 23(12): e76-e82. doi: 10.1158/1078-0432.CCR-17-0629.

10. The International Pleuropulmonary Blastoma/DICER1 Registry. [online]. Available from: www.PPBregistry.org.

11. European Cooperative Study Group for Pediatric Rare Tumors. [online]. Available from: www.raretumors-children.eu. 